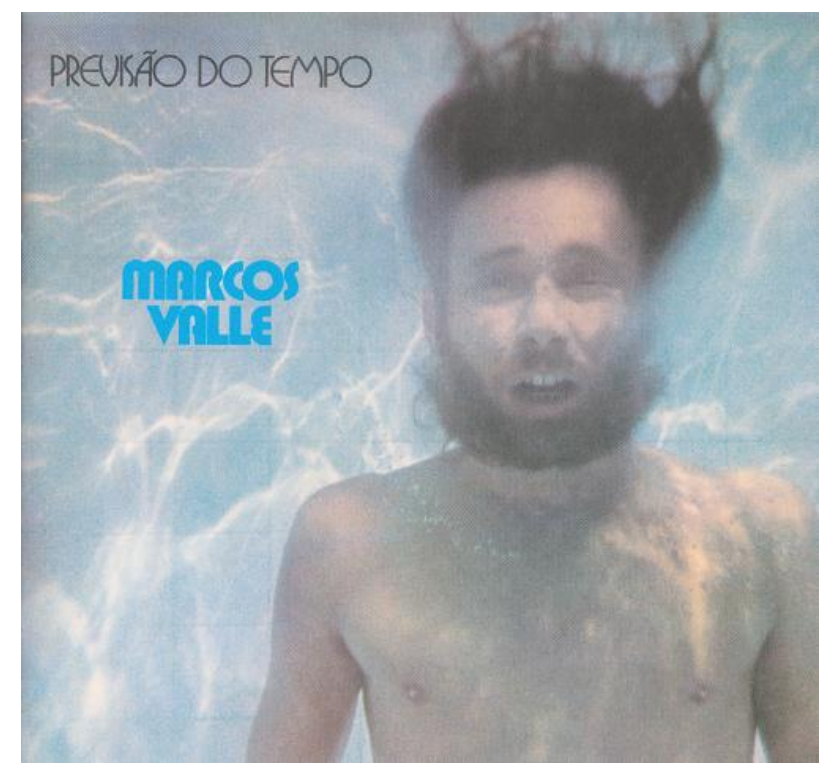

\title{
A MPB no regime militar: silenciamento, resistência e produção de sentidos
}

The MPB in the military regime: silenciment, resistance and production of senses

\author{
Ana Cláudia de Moraes Salles* \\ Olimpia Maluf-Souza** \\ Fernanda Surubi Fernandes***
}

Resumo: A censura imposta pelo governo militar produziu efeitos de subjugação sobre o povo brasileiro. Em meio a essa situação, objetivando transgredir o opressivo, destacava-se a MPB que incorporava em suas letras mensagens de insatisfação e de protesto. Assim, neste trabalho buscamos compreender as contradições produzidas a partir do discurso musical, dando visibilidade aos efeitos metafóricos pelos quais a língua funciona.

Palavras-Chave: Regime Militar, MPB, Censura, Contradição, Análise de Discurso.

Abstract: The censorship imposed by the military government produced subjugation effects upon Brazilian people. In the midst of this situation, aiming to transgress the oppressive, stood out the MPB which incorporated in its lyrics messages of dissatisfaction and protest. Thus, in this paper we aim to understand the contradictions produced in the musical discourse, giving visibility to the metaphorical effects by which the language works.

Keywords: Military Regime, MPB, Censorship, Contradiction, Discourse Analysis.

\footnotetext{
* Acadêmica do $8^{\circ}$ Semestre do curso de Letras Português/Inglês da Universidade do Estado de Mato Grosso (UNEMAT) e bolsista de iniciação científica PIBIC/CNPq. Endereço Postal: Rua São Jorge, 530, Bairro Cavalhada, Cáceres - MT. CEP: 78200-000. E-mail: anaaclaudia.salles@ gmail.com.

** Doutora em Linguística. Professora titular da graduação e da pós-graduação em Linguística pela Universidade do Estado de Mato Grosso (UNEMAT). É coordenadora do projeto de pesquisa Processos de autonomia, de produção e de identificação intelectual: a Análise de Discurso no Centro-Oeste. Endereço Postal: Rua do Lavapés, Quadra 01, Casa 06, Bairro Monte Verde, Cáceres - MT. CEP: 78200000. E-mail: olimpiamaluf@gmail.com.

${ }^{* * *}$ Mestre em Linguística pela UNEMAT. Professora do IFMT. Participa do projeto de pesquisa Processos de autonomia, de produção e de identidade intelectual: a Análise de Discurso no Centro-oeste. Endereço Postal: Rua da Tapagem, 912 Cáceres - MT. CEP: 78200-000. E-mail: fernandasurubi@gmail.com.
} 


\section{Introdução}

No período da Ditadura Militar, o Brasil esteve sob domínio governamental das Forças Armadas Nacionais. Nesse regime, a repressão foi instalada havendo muitos protestos, sobretudo na Música Popular Brasileira que foi silenciada pela censura prévia, pela qual as canções eram somente disponibilizadas ao público após avaliações. Essas avaliações feitas pelos censores do regime, não iam, muitas vezes, em direção ao desígnio do autor da música, o que resultou em desarmonias tanto entre censores e compositores quanto entre os próprios censores, colocando em relevo a incompletude da língua, que se marca pelos deslizes de sentido.

Diante dessa errância, desse movimento cambiante dos sentidos, procuramos compreender, pelos nossos gestos de interpretação, os discursos formulados em condições de produção específicas, como as da ditadura, tomando, assim, como objetivo analisar os modos como uma dada música produz diferentes efeitos de sentido, para distintas posições-sujeito, durante o Regime Militar.

Desse modo, a presente pesquisa busca analisar o funcionamento simbólico a partir da música Flamengo Até Morrer, composta em 1973, pelos irmãos Marcos e Paulo Sérgio Valle. Além da música mencionada, nosso material de análise compreende duas entrevistas cedidas por um dos compositores: uma à revista virtual thefrekium!, em 2006, e outra ao Jornal Correio Braziliense, em 2010, como também um pequeno trecho do livro Eu Não Sou Cachorro Não, que traz um comentário a respeito da canção com a qual trabalhamos.

Para tanto, em vista do corpus de pesquisa proposto, tomamos como base teórica a Análise de Discurso pecheutiana, enquanto uma área de conhecimento que compreende o discurso como sendo atravessado pela ideologia na história. Com base nessa perspectiva teórica, buscamos compreender, então, as condições de produção, as posições tomadas pelos sujeitos, como também a ideologia que os interpela, o silenciamento, a censura e a consequência iminente da opressão: a resistência.

\section{Ditadura e censura: as tentativas de interdição, de cerceamento e de tutela dos sentidos \\ O momento particular da Ditadura é tomado pela Análise de Discurso como} condição de produção que "[...] compreende fundamentalmente os sujeitos e a situação" (ORLANDI, 2012, p. 30). Por conseguinte, esse contexto histórico apresenta-se como um momento que muito significou no país, pois todos os seus acontecimentos afetaram 
os discursos e os sentidos provenientes destes, fazendo com que "[...] qualquer matéria significante explod[isse] os limites do sentido" (ORLANDI, 2007, p.123).

Esse período de opressão inicia-se com o golpe dos militares que, juntamente com a elite empresarial operaram, a todo o custo, para a restrição dos poderes de João Goulart, que assumiu a presidência do país após a renúncia de Jânio Quadros. Esse processo, iniciado por parte das Forças Armadas, desenvolveu-se em razão de considerarem a administração de 'Jango' arriscada para a política e para a economia do Brasil, pois poderia ser mergulhada nos ideais comunistas, aos quais as classes conservadoras e, essencialmente, capitalistas desejavam distância (BARROS, 2007). Essa situação dicotômica foi intensificada pela Guerra Fria, marcada pela disputa entre USA e URSS, em que ambas, sendo a primeira capitalista e a segunda socialista, tentavam reequilibrar a economia mundial pós Segunda Guerra com seus modos de administração adversos. Essa disputa tomou proporção mundial fazendo com que as nações filiassem-se à uma dessas formas administrativas. O Brasil, no início dos anos 60, demonstrava esse embate internamente com uma batalha entre capitalismo e um possível socialismo.

Durante os anos como presidente, João Goulart, em 1963 - quando o sistema presidencialista voltou a vigorar depois do parlamento instituído logo no início de sua posse - defendeu uma proposta denominada Reformas de Base que promoveriam uma reconfiguração na distribuição rentária. Tais ideias foram apoiadas por organizações como a União Nacional dos Estudantes (UNE), o Comando Geral dos Trabalhadores (CGT) e as Ligas Camponesas, ou seja, a classe baixa, trabalhadora e acadêmica do país, que viam nessas reformas indícios de melhora para a política e a economia do Brasil. Entretanto, pouco tempo depois da exposição dessas propostas, os militares, juntamente com o governo estadunidense, tomam o poder; "Jango" se vê obrigado a sair de cena e, assim, iniciam-se os "Anos de Chumbo". Nesse período, “[...] é fácil verificar a sucessividade de ações de forças destinadas a destruir franquias democráticas e a deter o avanço das forças populares em nosso país” (SODRÉ, 1984, p. 107).

Esse golpe político foi denominado pelos militares e adesistas como A Revolução de 31 de Março, pois, segundo eles, foi o primeiro passo do Brasil rumo a uma transformação político-social que repelia definitivamente o comunismo divisionista e derrotista, ${ }^{1}$ que punha em risco a integridade do país. A palavra revolução, empregada

\footnotetext{
${ }^{1}$ Retirado do discurso de Castelo Branco, primeiro presidente do Brasil após o golpe militar, proferido em 08/05/1964. In: Indursky, A fala dos quartéis e outras vozes, 1997.
} 
nessas circunstâncias, rememora os vários movimentos históricos considerados revolucionários, mas que, em grande parte, se contrapõem à natureza revolucionária militar. Conforme Indursky (1997, p. 103), a palavra “[...] 'revolução' nesse contexto produz uma grande ilusão discursiva, pois joga com o sentido que esse termo adquiriu com a Revolução Francesa", que se caracterizou pela derrubada do absolutismo monárquico pelas classes trabalhadoras oprimidas. Assim, nesse diferente cenário econômico, os militares, compreendendo as classes abastadas mercantilistas como o povo, começaram a agir em seu nome, enquanto os protestos dos demais - que também são povo, mas que são convenientemente esquecidos - têm sua "[...] voz silenciada e substituída por um simulacro da voz do povo" (Ibidem, p. 106) em sua coletividade, criando uma versão deturpada e manipulada dos anseios populares, ao produzir a unificação de vontades desse povo, que nunca foram as mesmas.

Observamos com esses acontecimentos, que no momento em que as massas visionavam perspectivas de mudanças, de possíveis melhorias de ordem pública, são bruscamente arrastados para uma nova administração que se mostraria, por muitos anos, como irredutível.

A Ditadura Militar do Brasil vigorou por pouco mais de duas décadas (19641985). Nesse período o país teve cinco presidentes: Castelo Branco, Costa e Silva, Médici, Geisel e Figueiredo, todos generais, portanto, ocupando altos cargos nas Forças Armadas e eleitos, supostamente, através de votos indiretos dos congressistas. Todavia, a sucessão na presidência terminava por ocorrer apenas entre a junta militar que oprimia e manipulava tanto o Congresso quanto os partidos políticos ainda existentes (FORNAZIERI, 2010). Durante a administração desses governantes foram instituídos dezessete Atos Institucionais que conferiam legitimação e legalidade às ações militares, como também, diversos Atos Complementares e Atos Excepcionais, que seriam incabíveis de acordo com as constituições pré-estabelecidas no Brasil. Essas ações eram disseminadas pelos presidentes e seus apoiadores, enquanto medidas necessárias de exceção, com vistas a repelir a sombra comunista e promover a reedificação da democracia. Por esse funcionamento

[...] os presidentes se veem e desejam ser vistos [como]: soldados convocados para cumprirem uma missão militar, a de salvar a pátria ofendida e ameaçada. Esta imagem, construída nos discursos presidenciais, aponta para o assujeitamento do soldado as decisões hierarquicamente superiores (INDURSKY, 1997, p. 59). 
Assim, observamos que os generais, que assumiram a presidência do país, colocaram-se praticamente como os heróis da pátria, como aqueles que estavam na incumbência de resgatar o país dos malefícios comunistas e naturalmente desejavam que a população brasileira também os visse dessa forma. Essa questão de tomar esse encargo e utilizar de todos os recursos legais, e quando ilegais, tornarem-nos permitidos (o que pode ser visto através dos Atos), nos mostra a ideologia militarista atravessando os sujeitos-militares/governantes: uma vez que os superiores destinavam aos hierarquicamente inferiores um encargo, estes não mediam esforços para cumpri-lo. Como diz Lenharo (1986, p. 199), “[...] o soldado é o exemplo mais acabado daquele que acata ordens, sempre à espera consciente de recebê-las. O soldado é um prisioneiro que vive um cotidiano altamente disciplinado, ‘[...] um prisioneiro que está satisfeito"”. Devido a essa condição, constitutiva do sujeito-militar, de submeter-se às diretrizes superiores, estes constroem o imaginário de que civis, no caso os brasileiros, também devam, de maneira natural, se subordinar piamente. Entretanto, os cidadãos não possuem essa formação, o que faz com que, no momento em que estão insatisfeitos com determinada situação, que lhes parece injusta, se rebelem. E como resposta aos protestos, os militares tentam firmar sua autoridade, por meio de ações despóticas e coercitivas.

Dessa forma, o Brasil em período militar é arremessado nesse ciclo de embates: imposição, interdição e opressão contra a resistência. Mas, os militares, ao verem que seus métodos repressivos ainda não eram suficientes para o controle absoluto que almejavam, restringiam ainda mais.

Umas das formas de controle, como dito, foram os Atos que tinham como objetivo burlar as leis aprovando medidas opressoras. Dentre esses atos, instaurou-se, em 1968, o AI-5, caracterizado por seu considerável enrijecimento, que concedeu poderes absolutos para o então presidente Artur da Costa e Silva, que obstou manifestações e abateu o "habeas corpus" no caso de crimes políticos, isto é, contra aqueles que resistiam de alguma forma às diretrizes coagidas. Dessa maneira, nesse período de vigilância, medidas de segurança estipuladas pelo governo foram firmadas, como a proibição de se frequentar certos ambientes, a 'liberdade' sondada, dentre outros direitos políticos restringidos.

Para controlar as manifestações contra o regime, foi instalada oficialmente, em 1972, a Divisão de Censura de Diversões Públicas (DCDP), sob o controle do Departamento de Polícia Federal. Esse órgão tem sua gênese em 1931 com o DOP, 
Departamento Oficial de Propaganda, criado por Getúlio Vargas, que posteriormente foi substituído, em 1934, pelo Departamento de Propaganda e Difusão Cultural (DPDC), que, em 1939, deu lugar a outra divisão que seguia os padrões das duas primeiras: o Departamento de Imprensa e Propaganda (DIP $)^{2}$. Essas três seções tinham como objetivo controlar não só as publicações artísticas, como também as midiáticas, disseminando informações convenientes ao governo com discursos patrióticos e adesistas. Assim, era conferida ao governo a exclusividade comunicativa e cultural do país.

Percebemos, com as coincidências entre as divisões do período autoritarista de Vargas e as do Regime Militar, que “[...] mesmo após a desmontagem da máquina ditatorial do Estado Novo, muitos de seus componentes perduraram e foram reativados na experiência ditatorial [que vigia]" (LENHARO, 1986, p.11). Desse modo, tendo como base os ditames das organizações da era Vargas, período que também aludia ditadura e controle, a DCDP (Divisão de Censura de Diversões Públicas), vigente no Regime Militar, tinha como tarefa avaliar previamente, as obras artísticas de todas as ordens, atentando-se desde questões morais, que iam contra os valores e os 'bons costumes', até aos protestos e às incitações de resistência.

Dentre as diversas categorias de produção artística; como o cinema, o teatro, o rádio, a televisão e a literatura; podemos dar destaque à Música Popular Brasileira como maior alvo dos cortes da censura. Vários cantores utilizaram desse gênero musical característico da identidade do país, devido à sua constituição miscigenada com origens indígenas, negras e europeias ${ }^{3}$ - para apresentar ideais de inconformismo, de oposição. Dessa maneira, a MPB possibilitou a esses compositores, enquanto gênero musical, a oportunidade de significar sentidos proibidos, pois “[...] apresentou-se não como um conjunto definido, fechado; mas até certo ponto diluído; um círculo de contornos não muito nítidos" (KRAUSCHE, 1983, p. 9), ou seja, um lugar de amálgama em que não há definições inexoráveis, pelo contrário, está totalmente aberta a corrupções, a comutações e tal como o simbólico (que o é), está em constante movimento. Portanto, nesse trabalho procuramos ver a música não apenas pela sua letra, mas também por sua construção melódica e harmônica, tomando-as como materialidade significante, propensa ao deslize, pois "[...] aquilo que faz sentido musical para um pode ser

\footnotetext{
${ }^{2}$ Censura Musical.com. Disponível em: www.censuramusical.com.br. Acesso em: 17 Jul. 2012.

3 Brasil Cultura. Origens da Música popular brasileira. Disponível em: $<$ http://www.brasilcultura.com.br/historia/origens-da-musica-popular-brasileira/>. Acesso em: 09 Mai. $\underline{2012 .}$
} 
inaceitável para outro, e o que se mostra interessante e até belo para uma pessoa pode deixar uma outra inteiramente indiferente (BENNET, 1986, p. 11, grifo do autor)". Logo, a música é também lugar de interpretação e de identificação dos sujeitos.

Dessa forma, grandes nomes da música como Milton Nascimento, Geraldo Vandré, Gilberto Gil, Caetano Veloso, Chico Buarque, dentre vários outros, engajaramse veementemente nessa causa e acabaram vetados, repreendidos e em alguns casos exilados. Entretanto, apesar do comprometimento desses músicos com a denúncia da opressão do governo, não eram todas as suas composições que continham tema político, mas, ainda assim, eram censuradas, ou seja, os avaliadores muitas vezes atribuíam sentidos às canções, que não correspondiam aos pensados pelos autores.

Os censores da DCDP possuíam a autoridade de vetar ou liberar as composições musicais, porém, podemos dizer que existia uma linha tênue entre essas duas sentenças. Os avaliadores eram orientados a vetar ao mínimo indício de protesto, entretanto, gestos de interpretação diferentes sempre surgiam, pois os sentidos migravam e é esse funcionamento da linguagem que pretendemos observar.

Diante das características da ditadura e da MBP, tomamos para análise a música Flamengo Até Morrer, composta por Marcos e Paulo Sérgio Valle. Compositores de vários sucessos, como Viola Enluarada e Terra de Ninguém, os irmãos Valle ganharam reconhecimento internacional com a música Samba de Verão.

Para esta análise, em vista do corpus proposto e de sua condição de produção, abordaremos, primeiramente, a censura, imposta pelo governo militar, na tentativa de adquirir controle absoluto sobre o conteúdo da imprensa e da arte, com os quais os cidadãos brasileiros entravam em contato.

Conforme Orlandi (2007, p. 104), a censura é “[...] a interdição da inscrição do sujeito em formações discursivas determinadas". Ou seja, os sujeitos não são autorizados a produzir certos discursos, pois estes são proibidos, vetados, uma vez que se apresentam como aquilo que poderia ser dito, mas que não o é, devido a certas interdições de posições a serem ocupadas.

A censura entra no campo da política do silêncio porque é forçada e imposta e subdivide-se em duas, com condições de produção diferentes: a constitutiva e a local. Orlandi (2007) diz que a censura, a que chama de local, relaciona-se ao intradiscurso, à formulação dos dizeres, e não ao interdiscurso, pois são sentidos possíveis, produzidos sócio-historicamente, porém obstados por algum poder. Mas, diz ainda, que também existe a censura constitutiva, que entra no plano do histórico fazendo com que certos 
sentidos não sejam sequer produzidos, sem que os sujeitos reconheçam isso, o que remete ao esquecimento $\mathrm{n}^{\mathrm{o}} 1$ discutido por Pêcheux, do nível ideológico ${ }^{4}$.

Nesse movimento pensamos a censura em uma indispensável relação com a metáfora, porque a censura é um espaço no qual reside a inclinação ao equívoco e, assim, à volubilidade significativa. A metáfora é amplamente discutida nos estudos linguísticos e é normativamente compreendida como a utilização de uma palavra que se afasta do seu sentido "normal". Na Análise de Discurso, questionaremos exatamente a denominada "normalidade" dos sentidos que captura os sujeitos, pois até mesmo a metáfora, conhecida amplamente como uma noção que produz o plurissignificativo, é limitada em sua definição. Queremos dar visibilidade, aqui, à metáfora não apenas como constitutiva na poesia - já que quando remete-se à essa figura, logo é posta na ordem literária - mas como imanente à linguagem em todas as suas modalidades e manifestações, o que concorda com as reflexões de Gadet e Pêcheux (2010), quando dizem que não há linguagem própria à poesia, como se tivéssemos que nos assujeitar à uma outra categoria de linguagem para produzirmos o poético.

Quanto a esse simplório pelo qual a metáfora, muitas vezes, é estigmatizada, Lacan (1999, p. 36) afirma que esta “[...] não é uma injeção de sentido, como se os sentidos estivessem em algum lugar, fosse onde fosse, num reservatório", isto é, num compartimento que seria aberto no momento em que se pretendesse edificar a transferência de sentidos e a não correspondência convencional entre significantes e significado. Essa é uma tomada muito prática da metáfora, que pretere a sua complexidade simbólica e da qual, por conseguinte, nos afastamos.

Em nosso trabalho observamos o efeito metafórico como aquilo que permite a falha e o desprendimento dos sentidos; que confunde, que intransparece e que causa suspeição. E que mesmo sendo muitas vezes propositalmente utilizada, funciona independentemente das intencionalidades do sujeito, aos seus discursos serem propagados. Assim, temos a metáfora pelo inconsciente, que é constituído por linguagem.

Portanto, o conceito de metáfora nos embasa no desenvolvimento de nosso trabalho e imbrica-se, como dissemos, não só à censura, mas também à falha na língua ocasionada pelo equívoco produzido quando a língua toca a história ou, mais

\footnotetext{
${ }^{4}$ Segundo Pêcheux (2009), o "esquecimento no 1" é aquele em que o sujeito se coloca como origem de tudo o que diz.
} 
especificamente, no que concerne à nossa materialidade: quando uma canção, composta no Regime Militar, produz interpretações variadas por diferentes posições-sujeito.

No período militar, a censura local era feita pela DCDP, departamento que tinha como função avaliar, atribuindo o veto ou a liberação às produções artísticas, a partir das formulações das letras das músicas pelos seus compositores. Com essa divisão instituída, houve autores que, em caso de vetos, recorriam das decisões dos censores, alegando categoricamente que suas músicas estavam isentas de qualquer crítica política. Mas, também compositores que afirmavam em entrevistas, depois de extinta a ditadura, que suas canções eram verdadeiros protestos e ainda assim eram liberadas. Esse funcionamento mostra o caráter cambiante da interpretação, pois, além de os censores interpretarem uma mesma composição de forma distinta, os compositores, por seu lado, tentavam firmar suas acepções mediante o objeto de sua autoria. Com isso vemos que as tentativas de unificação interpretativa são, portanto, inviáveis, pois, segundo Pêcheux (2012, p. 53), "[...] toda sequência de enunciados é linguisticamente descritível como uma série (léxico-sintaticamente determinada) de pontos de deriva possíveis, oferecendo lugar à interpretação.” O espaço da língua(gem) é exatamente onde o diferente, o outro sentido reside.

\section{FLAMENGO ATÉ MORRER: EMBATES ENTRE O SILENCIAMENTO E A RESISTÊNCIA NA/PARA A PRODUÇÃO DE SENTIDOS}

$\mathrm{Na}$ Análise de Discurso, tomamos os movimentos, os equívocos, como intrínsecos à língua, como elementos fundamentais na produção e na constituição de sentidos. Tendo isso em vista, procuramos compreender esse funcionamento da língua a partir da música Flamengo Até Morrer e das diferentes interpretações resultantes dela, durante o período de ditadura.

(1) Flamengo Até Morrer

Parece que finalmente, resolvemos o dilema,

Dario e Doval jogando juntos sem problema

Eu como um prato a menos

Trabalho um dia a mais

E junto um trocadinho

Pra ver o meu Flamengo

Que sorte eu ter nascido no Brasil 
Até o Presidente é Flamengo até morrer

E olha que ele é Presidente do País

Rogério na direita

Paulinho na esquerda

Dario no comando

E Fio na reserva

E o resto a gente sabe, mas não diz

E o resto é pau, é pedra, águas de março ou de abril,

Mas tudo agora é paz nesse País, nesse Brasil,

A gente já cresceu

E é tempo de aprender

Que quem nasceu Flamengo é Flamengo até morrer.

Flamengo Até Morrer é a música que abre o álbum, Previsão do Tempo ${ }^{5}$, lançado em 1973, por Marcos Valle. Ao nos atentarmos à letra da música, o efeito de evidência produzido é o da exaltação do amor ao futebol, que caracteriza grande parte dos brasileiros. Entretanto, essa música, como já dito, foi autorizada ao público durante vigor da Ditadura Militar no Brasil, marcada por imposição e opressão em que, como discutimos, há a censura que também pode ser o indício e a possibilidade de existência de sentidos distintos, que propendem à resistência de significar o não permitido.

Apesar dessa música aparentemente falar do logicamente estabilizado - o amor do brasileiro pelo futebol - podemos dizer que ela está repleta de ironias e críticas ao governo, pois, compõe-se, como todo discurso, de "[...] uma série heterogênea de enunciados, funcionando sob diferentes registros discursivos e com uma estabilidade lógica variável" (PÊCHEUX, 2012, p. 23). São esses funcionamentos que destituem a materialidade discursiva do arraigamento significativo e coloca o simbólico como construção não sólida, uma vez que está, a todo o momento, prestes a desmoronar, se dispersando para diversas direções. Vemos esse movimento de transferência desde os dois primeiros versos, nos quais se diz que enfim o grande dilema foi resolvido, porém o impasse, segundo a canção, não é a desordem e a repressão política que assolava o país, mas sim o entrosamento dos jogadores em campo. Ou seja, enquanto se preocupa com o futebol se ignora a política. Assim, dizendo do futebol o efeito que a canção produz como tema central é a alienação do brasileiro pelo esporte de maior popularidade nacional, o futebol.

\footnotetext{
${ }^{5} \mathrm{O}$ próprio nome do álbum de Marcos Valle - Previsão do Tempo - produz também efeitos sobre o momento do país, pois o tempo ali era o da ditadura.
} 
A música é constituída de várias insinuações sutis que são marcadas, em alguns momentos, por um certo tom de inconformidade e de denúncia mais acentuado. Assim, temos nos versos: e o resto a gente sabe, mas não diz/ e o resto é pau é pedra águas de março ou de abril. Podemos observar que esse trecho produz efeitos de denúncia sobre a acomodação do brasileiro que, envolvido pelo entretenimento do futebol, apesar de estar ciente da condição caótica do seu país, não faz nada a respeito, não se manifesta. O povo sabe, mas não diz com medo da repressão, das torturas, do exílio. $\mathrm{O}$ povo está ciente da condição, mas não fazer nada é efeito do próprio período militar, das condições de produção pelas quais esses sujeitos são interpelados. Ou seja, há um silenciamento da voz do povo que se aliena por não se sentir nas condições de poder fazer, poder dizer algo.

O recorte faz também menção à música Águas de Março (1972), composta por Tom Jobim, assim, o resto que os brasileiros sabem, mas não dizem, segundo o cantor e compositor bossa-novista, é o "pau", a "pedra", que aludem à dureza imposta pelo Regime Militar, ou seja, as palavras "pau”, "pedra" fazem significar os ditames e a rigidez às quais o país estava comodamente imerso. Assim, temos dizeres que memoram outros; temos diferentes discursos que se relacionam e que produzem diferentes sentidos, de acordo com a ideologia, que, segundo Indursky (1997), mesmo externa à formação discursiva, tece efeitos em seu interior.

Outro funcionamento que também significa na música em análise é a sua construção rítmica, harmônica e instrumental. Flamengo Até Morrer apresenta a estrutura rítmica de um samba, que é cadenciado pelo som de uma cuíca bem marcante. Tal gênero musical carrega brasilidade e exalta a nacionalidade, identificando o Brasil, como o país do samba, do carnaval e do futebol. A própria escolha desse ritmo, pelo autor, já produz efeitos e dá visibilidade ao patriotismo, que a gestão militar incutia na população, pois o povo brasileiro devia louvar e exaltar tudo o que prosperava no país e fazer vistas grossas ao caos econômico, às limitações dos seus direitos, à opressão.

Esse funcionamento podia ser notado também pelo slogan adesista "Brasil: Ame-o ou deixe-o"6, amplamente divulgado no período. O slogan funcionava, então,

\footnotetext{
6 Slogan criado no mandato de Médici. Naquele período o governo investia muito dinheiro em propagandas que objetivavam a melhora da imagem dos militares junto ao povo. Folha online, Brasil: ame-o ou deixe-o. Disponível em: <http://www1.folha.uol.com.br/folha/especial/2002/eleicoes/historia1969.shtml>. Acesso em: 10 Dez. 2013.
} 
como uma máxima do regime, convocando os brasileiros a amar o seu país pelo samba, enquanto um ritmo reconhecido e apreciado internacionalmente; a amar o país pelo futebol, que recentemente (1970) havia se tornado tricampeão mundial; a amar o país pelo carnaval, um dos maiores espetáculos do planeta e, em contrapartida, a alienar-se a respeito dos desmandos orquestrados pelos militares. Dito de outro modo, o que o slogan propunha era um amor incondicional, cego pelo país, pois quem não pudesse ter por ele essa forma de amor, deveria deixá-lo, ao invés de criticá-lo, de apontá-lo como faltoso, como opressor, como cerceador de toda a forma de expressão que não fosse aquela defendida pelos militares. Assim, se o país, da forma como estava, não fosse suficiente para os brasileiros, estes deveriam abandoná-lo, mas não protestar.

Da mesma forma, a música Flamengo Até Morrer nos mostra o mesmo funcionamento, pois, ao louvar sarcasticamente o amor incondicional dos brasileiros a um time de grande popularidade, como o Flamengo, critica a alienação pelo futebol, enquanto "paus" e "pedras" controlam o que todos sabem, mas fingem não saber. Logo, a música produz efeitos de apagamento da desordem política que imperava no país pela construção de um disfarce cultural e esportivo bem sucedido.

O samba é o ritmo eleito para a canção, entretanto, os modos como a cuíca e os outros instrumentos de percussão são tocados em um dado momento da música também produzem outros efeitos de sentido. A melodia alegre e dançante da música é amenizada e, repentinamente, torna-se lúgubre e suave.

Essas nuances melódicas não podiam sequer ser percebidas pelos censores, porque tinham em mãos apenas os versos da canção, portanto muito se perdia. A análise da DCDP no tocante à música dedicava-se, exclusivamente, ao que era dito, à linguagem verbal, enquanto que o não-verbal era praticamente ignorado. A música é a arte constituída pela harmonização entre sons e silêncio e a ausência de palavras, de maneira alguma, isenta as composições musicais de sentidos. A procura pela imposição do silêncio, feita pela ditadura, era falha, pois o vácuo que tentavam impingir não pode ser obtido. Os sujeitos utilizavam não só das palavras para produzir sentidos de revolta, o que não era dito também significava.

A possibilidade do sentido outro em canções a partir de características nãoverbais é argumentada por Souza que discorre a respeito das modulações de voz:

Assim se focamos a voz como lugar material desta composição, os traços acústicos e prosódicos que tecem o ritmo e a melodia do ato de enunciar - intensidade, altura, força, lentidão, rapidez -, suscitam 
interrogações a respeito do sujeito em vias de aparecer no rastro sonoro da emissão vocal. Este é o momento quando nada de aprioristicamente personológico é alcançável na voz. Em síntese, a voz é lugar-fonte no corpo, o mesmo de onde se emite o assovio, o riso, o choro, o grito, o canto. Tomo então a voz como pura enunciação exposta à obrigação de interpretar e ser interpretada, gesto dramático situado na coxia do teatro simbólico (SOUZA, 2000, p. 03).

Souza (idem) fala do acontecimento do canto, no qual o indivíduo assujeita-se e toma posições de acordo com as variações formuladas por sua voz, no discurso musical. Isso nos mostra os modos como a voz se coloca em diferentes temáticas (amor, protesto, ódio) e situações. Na música de Marcos Valle, o tom debochado, utilizado em grande parte da canção, remete ao "jeitinho brasileiro de ser" , da malandragem, da pilantragem.

A pilantragem pode ser entendida aqui de duas formas: a) enquanto gênero musical ${ }^{8}$ híbrido, que incorpora propriedades musicais de diferentes naturezas à música popular do Brasil; e b) com outro sentido atribuído ao termo por Simonal, no qual há a malemolência para se conseguir o que quer. Também inclui o burlar das regras, não em sentido militante, mas sim a questão da quebra das normas para promover um auto favorecimento. Em ambas as concepções, temos a irreverência do brasileiro, a sua tranquilidade e despreocupação, e que, como vemos na música, permaneciam mesmo na situação aflitiva causada pelo vigor da ditadura. Mas, existem dois momentos, em que o compasso entusiasmado acompanhado pela voz, torna-se sóbrio e entra em uma cadência bem contrastante com a anterior. $\mathrm{O}$ cantar fica vagaroso e atenuado e vai em direção à letra da música que salienta a rijeza militar; nesse conjunto entre melodia e voz, vistos nessa parte da letra, evoca-se um lamento.

Essas mudanças acontecem nos seguintes versos: "E o resto é pau, é pedra, águas de março ou de abril” e "A gente já cresceu/E é tempo de aprender”. O primeiro, como já analisamos, remete à opressão do regime, marcadas pelas palavras "pau" e

\footnotetext{
7 "Há certas imagens sobre o comportamento do brasileiro que permeiam as percepções das pessoas nas suas relações sociais. [...] Para a grande maioria dos brasileiros, a busca de atalhos, soluções facilitadas ou vantagens fazem parte do cotidiano das pessoas" - explica Rachel Meneguello, cientista política da Universidade de Campinas (Unicamp). O Globo: 'Jeitinho brasileiro': $82 \%$ acham que maioria pretende tirar vantagem, diz pesquisa. Disponível em: <http://oglobo.globo.com/brasil/jeitinho-brasileiro-82acham-que-maioria-pretende-tirar-vantagem-diz-pesquisa-11842428>. Acesso em: 22 de Jul. de 2014.

8 "Pilantragem, um projeto estético da década de 60, inventado por Simonal, Carlos Imperial e Nonato Buzar, buscava, como o Tropicalismo, fundir o que vinha 'de fora' com as tradições de 'de dentro"'. O Globo: Blog do Xexéu. Pilantragem, o gênero que a MPB esqueceu. Disponível em: < http://oglobo.globo.com/cultura/xexeo/posts/2011/08/03/pilantragem-genero-que-mpb-esqueceu395968.asp>. Acesso em: 22 de Jul. de 2014.
} 
"pedra" da música de Tom Jobim, também composta em período ditatório. O segundo verso, ao dizer que crescemos e já deveríamos saber que uma vez flamenguista, sempre flamenguista, permite-nos compreender essas sentenças como uma chamada, um alerta aos brasileiros, para atentarem-se e aprenderem que algo deve ser feito a respeito dessa opressão.

Esse mesmo dizer produz, ainda, efeitos de conformismo, a gente já cresceu, $e$ é tempo de aprender, ou seja, agora é tempo de conformar-nos e continuar sendo Flamengo até o fim. Como dito anteriormente, remete ao slogan Brasil: Ame-o ou deixe-o, pois diz que o brasileiro nunca deve mudar de time, ou seja, nunca deve mudar a posição a qual está submetido: a de acomodado e oprimido pela ditadura. Assim, percebemos a ambiguidade presente na música, o porquê da mesma ser liberada pelos censores e também a razão de outros autores tomarem-na como ufanista, causando contragosto aos compositores, como se verá a seguir.

Desse modo, apesar de todas essas possíveis formulações que sugerem críticas ao regime, a música não só é liberada pela DCDP, mas também interpretada como ufanista.

Esse acontecimento se marca pela entrevista de Marcos Valle, cedida ao Correio Braziliense, em 2010, na qual o cantor coloca qual foi o sentido que intencionava atribuir à música e que reação imaginava que esta provocaria.

(07) Entrevista Marcos Valle (2010)

A gente achou que a música daria uma confusão do cacete [...]. O narrador é o brasileiro totalmente alienado. Os jogadores entram na música como um exército convocado pela ditadura [...].

Como se pode notar na entrevista, Marcos compôs a música para falar da alienação que o brasileiro mantinha, através do futebol, ao portar-se de forma alheia aos problemas políticos do país. Tendo composto a música com o propósito de protestar contra a alienação do povo brasileiro frente aos desmandos da ditadura, o compositor acreditou que sua letra ocasionaria uma grande confusão e que seria, certamente, vetada.

A escolha do clube também não é aleatória, pois basta compreender que o autor, um torcedor do Botafogo, escolheu o Flamengo por se tratar do time que tinha/tem a maior e uma das mais apaixonadas torcidas brasileiras. Assim, naquele período, a alienação do brasileiro pelo futebol fazia com que tivesse apenas um dilema a 
resolver - Parece que finalmente, resolvemos o dilema, Dario e Doval jogando juntos sem problema -, qual seja, escolher a escalação e a posição de dois jogadores, Dario e Doval e não a de se posicionar politicamente contra um regime de massacre.

Na mesma direção, o que parece revelar, na música, a escalação do Flamengo Rogério na direita, Paulinho na esquerda. Dario no comando. E Fio na reserva -, produz efeitos que metaforizam posições políticas: ser de esquerda, de direita, estar no comando, estar na reserva. Ou seja, o efeito produzido pela música diz também de posições políticas assumidas diante do regime, pois diz daqueles que estão com o governo: os de direita, os que estão no comando; e dos que estão contra, os de esquerda, os na reserva. Pelo deslizamento metafórico, vemos como música e letra são, ao mesmo tempo, um apelo à evidência e à resistência. É, pois, esse efeito contraditório da música que faz com que ela seja liberada, considerada ufanista, adesista, etc.

A crítica sutil que a música faz ao processo de alienação pelo futebol, atinge, inclusive, ao presidente do país - Até o Presidente é Flamengo até morrer / E olha que ele é Presidente do País, pois faz alusão ao Presidente militar, Médici, que não perdia um jogo do Flamengo, acompanhando todos os lances, colado ao seu radinho de pilha. Ou seja, a eficácia da alienação pelo futebol era tão considerável que até mesmo o comandante de toda a opressão se deixava levar por ela.

Ainda no que diz respeito ao clube elegido para destaque na canção, questionamo-nos sobre o porquê de o time ser carioca e não paulista, já que ambos os estados possuem homogeneidade compatíveis e semelhantes no que tange à conquista de títulos e reconhecimento. Compreendemos que por o Rio de Janeiro ser o lugar onde surge a Bossa Nova, o Samba, o Carnaval, pelos quais o Brasil tem grande êxito no exterior; e por ser o cartão postal do país, em razão das suas belezas naturais, que exportam uma imagem paradisíaca e que colocam o Brasil em posição privilegiada, objetiva-se, com a escolha do Rio de Janeiro, a edificação de uma fachada de um país com atributos aparentemente estonteantes, mas que na verdade esconde as mazelas trazidas pela administração tirana. Temos a alegria, o talento e a beleza física, representados pelo Rio, tentando mascarar o desespero e o arruíno. Portanto, nenhuma cidade brasileira congrega, ao mesmo tempo, tamanha contradição, pois é a cidade do moderno e do antigo, das belezas naturais e das artificiais, dos edifícios modernos/das mansões e dos morros/favelas, das gritantes diferenças sociais e econômicas, do samba, do carnaval, das mulheres belas e desnudas, do time de maior torcida/maior alienação, o Flamengo. 
Assim, não é trivial que o Flamengo, a maior torcida do país, ganhe lugar de destaque na canção. Nessa direção, poderíamos dizer que, assim como a maior parte dos brasileiros são torcedores do Flamengo, a maior parte dos brasileiros também é alienada pelo futebol. Tomar o Flamengo é fazer funcionar os sentidos de massa, não de uma massa que recentemente foi às ruas gritar contra os desmandos do governo, mas o de uma massa constantemente alegre e feliz, mesmo diante dos problemas sociais, econômicos e políticos do Brasil.

Na construção musical fala-se, como sempre, do mesmo futebol e da paixão que o povo tem por ele. Em um movimento de paráfrase, retornamos a esse tema e ao que já foi construído e estabelecido a respeito dele, mas nessa atual enunciação, apesar do discurso ter se fundado por essa memória, os sentidos não são mais os mesmos, se deslocam em um movimento de polissemia. Desse modo, apesar do aparente louvor ao esporte, que se cristalizou, há uma ruptura nessa rede semântica que faz com que Flamengo Até Morrer possa fugir do evidente. Por esse processo, confirmamos que os sujeitos e os discursos são feitos devido ao jogo dinâmico entre o parafrástico e o polissêmico (ORLANDI, 2012).

Apesar de todas essas formas irônicas de oposição, a música além de liberada, pelo fato de os censores não compreenderem o seu caráter oposicionista, foi também interpretada como adesista ao regime, tanto na época da sua publicação quanto na atualidade, pois, em 2002, um historiador escreveu que a música Flamengo Até Morrer demonstrava ser patriótica.

Marcos Valle fala sobre o caso para a revista eletrônica Thefrekium, em entrevista cedida em 2007:

(08) Entrevista Marcos Valle (2007) $)^{9}$

TF - Flamengo Até Morrer costuma ser citada como uma canção simpática ao governo, quando é exatamente o contrário. [...] É bem debochada até...

MV - Totalmente debochada! Até quando a gente fala: Fio na reserva, Dario no comando/ E o resto a gente sabe mas não diz... a gente tá sacaneando o exército, mostrando que na verdade quem comandava o povo era a alienação causada pelo futebol. Era essa a sacanagem da música. Teve um cara que escreveu um livro e não entendeu nada. TF - O Paulo César de Araújo no livro Eu não sou cachorro não...

\footnotetext{
${ }^{9}$ No recorte da entrevista, as legendas TF e MV referem-se respectivamente à Revista Thefrekium e a Marcos Valle.
} 
MV - Não é impossível que ele tenha interpretado como favorável ao exército. A música era realmente pra dar uma sacaneada total no governo...

TF - Essa passou pela censura?

MV - Passou!

TF - Até devem ter gostado!

MV - Eles não devem ter entendido, assim como o cara do livro.

Nessa entrevista, o próprio Marcos diz que não é impossível que as pessoas tenham interpretado a música como favorável ao governo, mas que não entenderam, ou seja, que os sentidos não foram apreendidos pelos interlocutores do modo como o pretendido pelo autor, não havendo, portanto, compreensão por parte dos ouvintes, como se o distanciamento semântico entre o sentido pretendido pelo autor e o interpretado pelo interlocutor fosse uma deturpação, uma incapacidade do interlocutor de interpretar conforme o esperado. Todavia, pela Análise de Discurso, estamos instados a interpretar, assim, não concebemos a interpretação como erro, mas como produto da relação entre história e ideologia que, por sua vez, se edifica na língua(gem), que é própria de cada posição-sujeito. Na visão do compositor, os sentidos que a música deve produzir são únicos, aqueles pretendidos pelo autor, pois ele está interpelado por uma ideologia cujo dizer tem sentido único, transparente. Por esse entendimento, os sentidos são sempre os pretendidos por quem enuncia. Pela ideologia, a evidência toma o sujeito, o enclausura em um recinto de determinada significação, a ponto de não permitir com que reconheça a possibilidade de diferentes sentidos, devido à natureza inconsciente desse processo.

No momento em que o compositor diz que compreende a possibilidade de o sentido ter tomado essa direção, porque a finalidade da música era realmente dar uma sacaneada total no governo, percebemos que houve aí uma tentativa, por parte dos autores, de camuflar a natureza crítica da música, ou, dito de outra forma, procuraram driblar a censura, usando a ironia que jogou com a dubiedade de forma a atribuir à canção uma crítica que fica subsumida pelo tema do enaltecimento do futebol. Dessa maneira, a composição pauta-se em um assunto tão disseminado, tão comentado, tão lugar-comum que cristaliza os sentidos, criando "[...] condições para que o sujeito não apareça, diluindo-se na universalidade indistinta" (ORLANDI, 2007 p. 126). É nesse espaço que se instala o estereótipo, que se torna o lugar no qual o sujeito, contraditoriamente, encontra a possibilidade de instituir o dessemelhante. Por apresentar-se trivialmente como o clichê, a padronização, o lugar do consentimento 
indiscutido, o estereótipo pode trabalhar, em condições de censura, como espaço de resistência e de irrupção do equívoco, pois não só magnetiza os sentidos, como se é concebido convencionalmente, mas também os repele em um processo de reconhecimento e de afastamento. É, então, daquilo que se repete à exaustão, daquilo que estagna os sentidos que surge o desconcerto, o deslize.

$\mathrm{Na}$ língua, o processo entrecruzado de discursos, de posições, de sentidos nunca se estanca e sempre dá lugar à falha; “[...] dizemos o mesmo para significar outra coisa e dizemos coisas diferentes para ficar no mesmo sentido" (ORLANDI, 2007, 94). São esses deslocamentos que observamos na relação entre a censura e a resistência, pois o querer dizer o proibido dá vazão a diferentes gestos de interpretação.

$\mathrm{Na}$ entrevista, vemos o autor da música tentar explicar o que tentou significar, com questões como a alienação e a escalação dos jogadores como um exército convocado pelos militares. Entretanto, ainda hoje a música continua não produzindo esses sentidos, tanto que atualmente ainda é reproduzida como um hino, pelos flamenguistas ${ }^{10}$. Isso se deve, principalmente, ao fato de não ser mais aquele momento histórico, de não se ter memória do que significou a ditadura, assim, pode-se até saber que a música foi composta durante o Regime Militar, mas os mesmos efeitos já não são produzidos depois da extinção dela. É outra situação histórica, que implica outros sentidos.

Diante disso, notamos que o autor Marcos menciona na entrevista um caso interessante, no qual um escritor publica um livro colocando Flamengo Até Morrer na categoria de ufanista.

(09) Trecho do livro Eu não sou cachorro, não, de Paulo César de Araújo (2002, p. 357)

Mesmo os irmãos Marcos e Paulo Sérgio Valle, que na década de 60 compuseram canções de crítica social, após a Copa do Mundo de 1970, apareceram [...] com o samba Flamengo até morrer, que em um de seus versos diz: "Que sorte eu ter nascido no Brasil / até o Presidente é Flamengo até morrer / e olha que ele é o Presidente do país", enfatizando o fato de o presidente Médici cultivar a imagem de amante do futebol e aparecer nas tribunas do Maracanã com radinho de pilha ao ouvido torcendo para o mais popular clube brasileiro. Como observou o escritor Edilberto Coutinho, "creio que devemos dar razão a quem achou a letra dos Valle meio patrioteira".

\footnotetext{
${ }^{10}$ Acreditamos que, mais do que atribuir a permanência da música aos que desconhecem e aos que não têm memória do que significou o momento histórico da ditadura, a manutenção da música se faz em razão de ela ter sido liberada e de ter sido considerada um hino de amor ao Flamengo e à pátria.
} 
O livro, Eu não sou cachorro não, lançado em 2002, fala sobre a inconformidade política no período da ditadura, através da música brasileira, principalmente a brega - como já sugerido pelo título ${ }^{11}$. $\mathrm{O}$ autor faz um percurso pelas músicas de protesto compostas durante o Regime Militar, dando foco ao brega, ao afirmar que, apesar de ter sido deixado de lado, figurou grande importância no cenário musical do país daquele momento.

Em um dos capítulos de seu livro, Ufanismo e guerrilha, são trazidos compositores que, segundo o historiador, se dedicaram a escrever músicas patrióticas, que vangloriavam o governo ditador, assim, artistas como Don e Ravel, Jorge Ben Jor, etc. são citados. Mas a surpresa maior foi a referência aos irmãos Valle, que apesar de já terem lançado músicas de cunho crítico social e político ${ }^{12}$, foram, com Flamengo Até Morrer, tachados de ufanistas.

Paulo César de Araújo ao tomar a música como adesista apaga tudo o que poderia soar como resistência, até mesmo o repertório anterior de protestos dos compositores é esquecido e não afeta a interpretação. Assim, a música, para o autor do livro, é vista como uma glorificação à imagem do então presidente Emílio Garrastazu Médici, que era declaradamente um flamenguista apaixonado por futebol.

Visualizamos com os dizeres desse historiador outra interpretação da música que mais uma vez desloca-se daquilo que foi proposto pelo autor, pois ele, conforme afirma Orlandi (2007, p. 123), “[...] já não decide: ele mesmo faz parte do funcionamento dos sentidos que inaugurou. Ele é parte do 'evento histórico' que se instalara no jogo entre censura e resistência", uma vez que ambos os funcionamentos são coexistentes, ou seja, um implica o outro, pois não há repressão sem resistência. A repressão e a revolta constituem-se através de um relacionamento mútuo, do mesmo modo como acontece com a língua e sua falha inerente, apesar de procurarmos seu

\footnotetext{
11 "Eu Não Sou Cachorro, Não" é o título da música de maior sucesso do cantor baiano Waldick Soriano, um dos ícones da música brega. O nome da música se tornou expressão popular no Brasil, fazendo referência ao desprezo e ao rechaço não merecido. Tal como aconteceu, segundo Araújo, com a música brega na ditadura. Folha Online. Conheça curiosidades da vida do cantor Waldick Soriano, 2008. Disponível em: <http://www1.folha.uol.com.br/folha/ilustrada/ult90u441262.shtml >. Acesso em: 14 Dez. 2013.

${ }^{12}$ Marcos e Paulo Sérgio Valle já haviam composto canções com temas de favela ("Maria da Favela" e "Tião Braço Forte"); políticas agrárias como em "Terra de ninguém", "Gente" e "Deus brasileiro". E ainda, posteriormente, sobre o assassinato de Che Guevara ("Réquiem", 1968, cantado em dupla com Milton) e sobre a Passeata dos Cem Mil ("Dia de vitória", 1969, com o conjunto de jovem guarda Golden Boys). Revista Forum. O hibridismo musical de Marcos Valle, 2012. Disponível em: $\langle$ http://revistaforum.com.br/blog/2012/02/o-hibridismo-musical-de-marcos-valle/>. Acesso em: 16 Nov. 2014.
} 
regramento, sua solidez, seu controle o que encontramos são furos que não podem ser tapados e arestas que não podem ser aparadas, pois são essas irregularidades que cumprem a natureza da língua e que permitem seu funcionamento inquieto.

\section{Considerações finais}

As análises realizadas nos permitem afirmar que não há nada que garanta a tutela dos sentidos intencionados pelos sujeitos, entretanto, todos nós somos interpelados por uma ideologia que nos dá a ilusão constitutiva de que somos a fonte e a origem do dizer e de que o que dizemos tem apenas o sentido pensado por nós. Procuramos, assim, singularizar uma língua que é incompleta e que funciona por essa incompletude, por esses equívocos que se inscrevem na língua continuamente.

Observamos esses sentidos em funcionamento na música Flamengo Até Morrer, pois, como vimos, trata-se de uma música que foi composta com a intenção de construir uma crítica feroz ao regime e que, paradoxalmente, foi interpretada como louvadora do país e dos seus gestores.

Compreendemos o paradoxo que se causou entre a intenção do autor e os efeitos produzidos pela música como modos de interpretações de sujeitos interpelados por uma dada ideologia que

[...] fornece as evidências [...] que fazem com que uma palavra ou um enunciado 'queiram dizer o que realmente dizem' e que mascaram, assim, sob a 'transparência da linguagem', o [...] caráter material do sentido das palavras e dos enunciados. (PÊCHEUX, 2009, p. 146)

Desse modo, como diz Pêcheux, percebemos que a língua não é transparente e que uma palavra ou um enunciado não significam a partir de um sentido apenas seu, que não pode ser mudado e que esteja preso ao literal. A língua funciona, portanto, pelo atravessamento necessário da historicidade e da memória, que resultam em formulações de discursos e de sentidos cortados pela falha. Essa “[...] irrupção do equívoco afeta o real da história, o que se manifesta pelo fato de que todo processo revolucionário atinge também o espaço da língua [...]" (GADET; PÊCHEUX, 2010, p. 64), do mesmo modo como pôde ser visto com a Ditadura Militar do Brasil, que produziu efeitos em todo espaço linguístico da época, como nos foi mostrado nesse trabalho mais especificamente com a música. O que podemos dizer então, é que a tentativa de instituição de um mecanismo de censura governamental foi frustrada e ineficiente, pois a partir do momento que compreendemos que o sujeito não só tece interpretações, mas é resultado 
dessas interpretações, se significando por elas, compreendemos ainda que não existe censura que não seja burlada pelo sujeito, através do simbólico, pois, mesmo que inconscientemente, não existe linguagem que se permita aprisionar.

\section{Referências bibliográficas}

BARROS, Cézar Mangolin de. A Ditadura Militar no Brasil: processos, sentidos e desdobramentos. 2007. Disponível em: http://cesarmangolin.files.wordpress.com/ 2010/02/cesar-mangolin-de-barros-a-ditadura-militar-no-brasil-2011.pdf. Acesso em: 27 out. 2013.

BENNET, Roy. Uma breve história da música. Tradução: Maria Tereza Resende. Rio de Janeiro: Ed. Jorge Zahar, 1986.

FORNAZIERI, Lígia Lopes. Ditadura militar. Historiando, Nov. 2010. Disponível em: $<$ http://historiandonanet07.wordpress.com/2010/11/15/ditadura-militar/>. Acesso em: 27 Out. de 2013.

GADET, Françoise; PÊCHEUX, Michel. A língua inatingível: o discurso na história da linnguística. 2. ed. Campinas, SP: Ed. RG, 2010.

INDURSKY, Freda.A fala dos quartéis e outras vozes. Campinas, SP: Ed. Unicamp, 1997.

KRAUSCHE, Valter. Música popular brasileira: da cultura de roda à música de massa. São Paulo, SP: Brasiliense, 1983.

LACAN, Jacques. O Seminário, livro 5: as formações do inconsciente. Tradução de Vera Ribeiro; revisão de Marcus André Vieira. Rio de Janeiro: Jorge Zahar, 1999.

LENHARO, Alcir. Sacralização da política. 2. ed. Campinas, SP: Ed.Unicamp, 1986.

ORLANDI, Eni.Análise de Discurso: Princípios e procedimentos. 10. ed. Campinas, SP: Pontes, 2012.

As formas do silêncio: no movimento dos sentidos. 6. ed. Campinas, SP: Editora da Unicamp, 2007.

PÊCHEUX, Michel. Discurso: estrutura ou acontecimento. 6. ed. Campinas, SP: Pontes, 2012.

2009. Semântica e discurso. 4. ed. Campinas, SP: Editora da Unicamp.

SODRÉ, Nelson Werneck. 1984. Vida e morte da ditadura: 20 anos de autoritarismo no Brasil. Petrópolis, RJ: Vozes.

SOUZA, Pedro. O sujeito no discurso: modulações operadas pelo drama na voz. Disponível em: $\quad \underline{\text { http://www.academia.edu/4016382/O_sujeito_no_discurso_ }}$ modulacoes_operadas_na_voz >. Acesso em: 14 Nov. de 2014.

Data de Recebimento: 20/12/2014

Data de Aprovação: 11/13/2015 


\section{Para citar essa obra:}

SALLES, A. C. M., MALUF-SOUZA, O., FERNANDES, F. S. A MPB no regime militar: silenciamento, resistência e produção de sentidos. In: RUA [online]. $\mathrm{n}^{\mathbf{0}}$. 21. Volume 2, p. 341 - 361. ISSN 1413-2109. Novembro/2015. Consultada no Portal Labeurb - Revista do Laboratório de Estudos Urbanos do Núcleo de Desenvolvimento da Criatividade.

http://www.labeurb.unicamp.br/rua/

Capa: Disponível em http://flabbergasted-vibes.blogspot.com.br/2011/11/marcos-valleprevisao-do-tempo-1973.html.

\section{Laboratório de Estudos Urbanos - LABEURB}

Núcleo de Desenvolvimento da Criatividade - NUDECRI

Universidade Estadual de Campinas - UNICAMP

http://www.labeurb.unicamp.br/

\section{Endereço:}

LABEURB - LABORATÓRIO DE ESTUDOS URBANOS

UNICAMP/COCEN / NUDECRI

CAIXA POSTAL 6166

Campinas/SP - Brasil

CEP 13083-892

Fone/ Fax: (19) 3521-7900

Contato: http://www.labeurb.unicamp.br/contato 